\title{
DINÂMICAS E ESPACIALIDADES DAS FEIRAS LIVRES NAS FRONTEIRAS ENTRE BRASIL-BOLIVIA E BRASIL-PARAGUAI
}

\author{
Dynamics and spatiality of free fairs on the borders between Brazil-Bolivia and Brazil- \\ Paraguay \\ Dinámicas y espacialidades de las ferias libres en las fronteras entre Brasil-Bolivia y \\ Brasil-Paraguay
}

\author{
Éder Damião Goes Kukiel \\ Érica dos Santos Oliveira** \\ Claudia Vera da Silveira ${ }^{\star * \star}$ \\ *Doutorando do Programa de Pós-Graduação em Geografia-PPGG/UFGD \\ - kukielgeografia@gmail.com. \\ **Mestranda do Programa de Pós-Graduação em Geografia-PPGG/UFGD \\ - ericasantos566@gmail.com \\ ***Doutoranda do Programa de Pós-Graduação em Geografia-PPGG/UFGD \\ - gycvera@gmail.com
}

Recebido em 28/01/2020. Aceito para publicação em 28/03/2020

Versão online publicada em 05/05/2020 (http://seer.ufrgs.br/paraonde)

\begin{abstract}
Resumo:
Este trabalho tem como objetivo analisar as dinâmicas e espacialidades feiras livres nas fronteiras entre Brasil-Bolívia e Brasil-Paraguay, nos municípios de Corumbá, Ladário e Ponta Porã, ambos no estado do Mato Grosso do Sul, e a cidade de Pedro Juan Caballero no Departamento de Amambay, Paraguai. Como procedimento metodológico utilizou-se de pesquisa bibliográfica e documental, cartografia e conversas dirigidas com agentes participantes dessa pesquisa. Os resultados indicam que essas feiras localizadas nas cidades fronteiriças representam locais de encontro e trocas, onde se comercializam diversos produtos com destaques para as hortaliças, hortifrutis, roupas e comidas típicas. Verificou-se que a fronteira se faz presente na forma como esses produtos são adquiridos e circulam nesse espaço ou mesmo quando ocorrem às fiscalizações de instituições públicas.
\end{abstract}

Palavras-chave: Feira livre. Fronteira. Comércio.

\begin{abstract}
:
This paper aims to analyze the dynamics and spatiality of free markets at the borders between Brazil-Bolivia and Brazil-Paraguay, in the municipalities of Corumbá, Ladário and Ponta Porã, both in the state of Mato Grosso do Sul, and the city of Pedro Juan Caballero. at the Amambay Department, Paraguay. As methodological procedure we used bibliographic and documentary research, cartography and conversations directed with agents participating in this research. The results indicate that these fairs located in the border cities represent meeting places and exchanges, where various products are marketed with highlights for vegetables, clothes, clothes and typical foods. It was found that the frontier is present in the way these products are acquired and circulate in this space or even when they occur under the supervision of public institutions.
\end{abstract}

Key-words: Free fair. Border.Trade.

\section{Resumen:}

Este artículo tiene como objetivo analizar las dinámicas y la espacialidades de las 
ferias libres en las fronteras entre Brasil-Bolivia y Brasil-Paraguay, en los municipios de Corumbá, Ladário y Ponta Porã, ambos en el estado de Mato Grosso do Sul, y la ciudad de Pedro Juan Caballero en el departamento de Amambay, Paraguay. Como procedimiento metodológico se utilizó revisión bibliográfica y documental, cartografía y conversaciones dirigidas con los agentes que participan en esta investigación. Los resultados indican que estas ferias localizadas en las ciudades fronterizas representan lugares de encuentro e intercambios, donde se venden diversos productos como verduras, frutas, legumbres, ropa y alimentos típicos. También verificamos que la frontera está presente en la forma de adquisición y circulación de los productos que se adquieren en este espacio, incluyendo los momentos de inspecciones realizadas por las instituciones públicas.

Palabras-clave: Ferias libres. Frontera. Comercio.

\section{Introdução}

Os primeiros relatos sobre feiras livres remetem a idade média na Europa, resultados de festas religiosas, onde mercadores aproveitavam a reunião dessas pessoas em tais festejos para a venda de seus produtos (Sato, 2007 p.97). No Brasil as primeiras feiras remetem ao período colonial com o comércio gêneros alimentícios, especiarias, tecidos em sua maioria importados e exposição e venda de escravos (Santo e Oliveira, 2012 p.4).

Este trabalho tem como objetivo analisar a dinâmica e espacialização das feiras livres nas fronteiras entre Brasil-Bolívia e Brasil-Paraguay, nos municípios de Corumbá, Ladário e Ponta Porã, ambos no estado do Mato Grosso do Sul, e a cidade de Pedro Juan Caballero no Departamento de Amambay, Paraguai. Vale ressaltar que são fronteiras com arranjos espaciais diferentes, sendo a fronteira entre Corumbá, lado brasileiro, e Puerto Quijarro, lado boliviano, considerado semi-cornubado (Machado, 2005) e entre Ponta Porã, lado brasileiro, e Pedro Juan Caballero, lado paraguaio, como conurbadas ( Benedetti, 2011).

Como metodologia utilizamos entrevistas com um total de 20 feirantes, sendo 06 no município de Corumbá, 04 em Ladário e 05 Ponta Porã no lado brasileiro da fronteira e em Pedro Juan Caballero no lado paraguaio foram entrevistados 05 feirantes. Foram feitas converas dirigidas com consumidores que frequentam as feiras nesses municipios mencionados entre os meses de maio a julho de 2019. Também utilizou-se de observações, dados cartográficos para espacializar as feiras e pesquisa bibliográfica relacionadas ao tema proposto.

As feiras nessas fronteiras representam locais de trocas e de encontro de culturas e identidades. São canais de comércios dos produtos locais como brasileiros, bolivianos e paraguaios. Além disso essas feiras livres fazem parte do cotidiano dessas populações fronteiriças que usam o local como ponto de encontro, logo, as feiras já fazem parte da dinâmica dessas cidades.

ParaOnde!?, Porto Alegre, v.13, n.2, p. 165-182, 2020.http://seer.ufrgs.br/paraonde Edição Especial - VII Seminário Internacional de Estudos Fronteriços 


\section{Feiras livres nos municípios fronteiriços de Corumbá e Ladários-MS}

No município de Corumbá existem nove locais onde ocorrem as feiras livres, de forma geral, são realizadas em bairros com a ocorrência de segunda a domingo, atendendo todas as regiões da cidade de Corumbá e Ladário-MS. De acordo com Silva (2003), as primeiras feiras se localizavam na parte central da cidade, com posterior expansão para os bairros afastados do centro da cidade de Corumbá.

Já em relação a participação de bolivianos, de acordo com Silva (2003), inicialmente estiveram presentes com um local próprio, que se localizava na rua Joaquim Mortinho, próximo à estação ferroviária da cidade.

Em Ladário as feiras ocorrem em cinco dias da semana, somente nas segundas e sextas - feiras, não há ocorrências de feiras livres, na cidade. Elas são realizadas tanto na parte central, na quarta-feira e no sábado. Já na parte alta da cidade ocorrem nos demais dias (Figura 1).

Figura 1 - Distribuição semanal das feiras livres por Corumbá e Ladário.

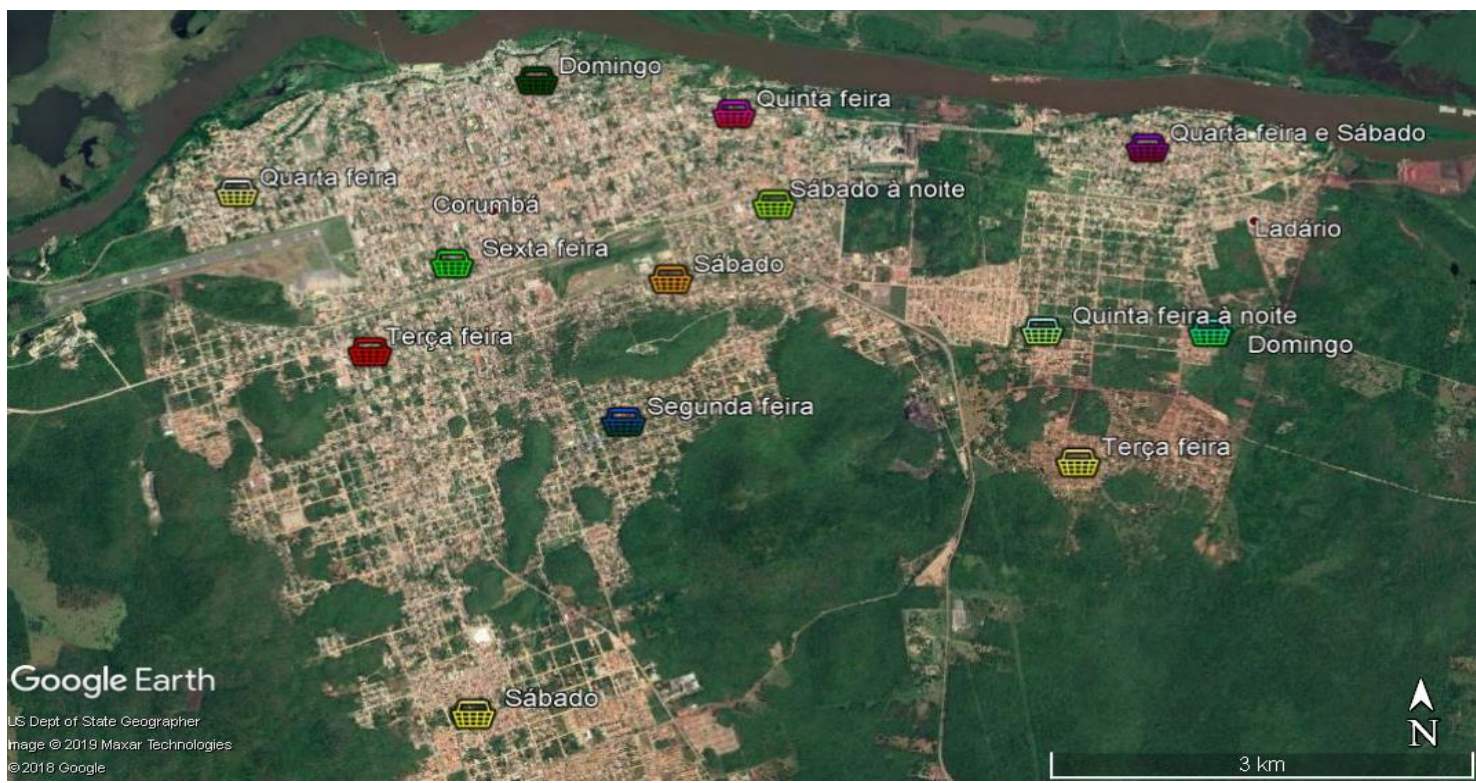

Fonte: Imagem Google Earth (2019)

Nos dias atuais observamos a forte presença dos feirantes bolivianos em todas as feiras que ocorrem tanto na cidade de Corumbá como na cidade de Ladário. São em maior quantidade quando comparamos com os feirantes brasileiros, oferecendo uma vasta gama de produtos.

Em relação a comercialização dos produtos naturais, há uma quantidade significativa de bancas de hortaliças, frutas e legumes oriundos de feirantes moradores dos assentamentos localizados em Corumbá, onde ofertam aos clientes, o que é produzido em suas propriedades, se destacam produtos como a mandioca, o feijão, o tomate, o tomate-cereja, a abóbora, a melancia e o limão, já entre as hortaliças, observamos a oferta de alface, couve, rúcula e agrião. Também se destacam produtos como ovos de galinha e até mesmo a

ParaOnde!?, Porto Alegre, v.13, n.2, p. 165-182, 2020.http://seer.ufrgs.br/paraonde Edição Especial - VII Seminário Internacional de Estudos Fronteriços 
oferta de carne de animais de oriundos de criação própria, como a carne de galinha caipira, porco e carneiro, como figura 1.

Quando comparados com o quantitativo de feirantes bolivianos, os feirantes brasileiros são em números bem inferiores e vendem apenas o que produzem, vivem nos assentamentos locais e frequentam a cidade para comercializar seus produtos.

\section{Figura 2 - Produtos comercializados pelos feirantes dos assentamentos locais na feira de sábado no centro de Ladário.}

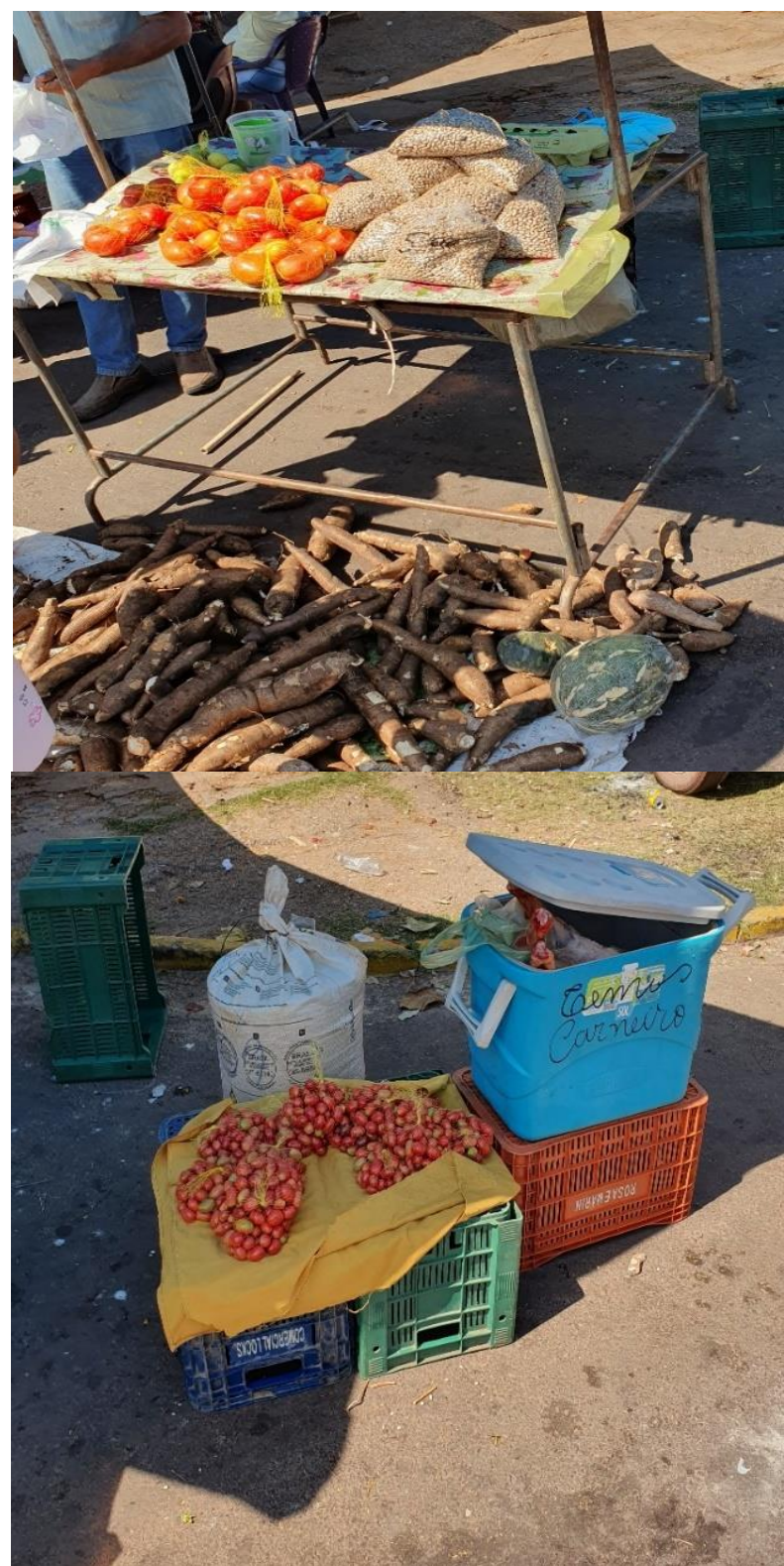

Fonte: Trabalho de campo 2019.

Já os feirantes bolivianos, comercializam produtos tanto dos assentamentos rurais brasileiros, como produtos advindos do lado boliviano da fronteira, onde também se produz hortaliças e verduras, e nos dias de feiras, transportam os produtos das cidades bolivianas próximas a fronteira, até local 
da feira livre.

De forma geral é perceptível a quantidade maior de produtos ofertados pelos bolivianos quando os comparamos com os oferecidos nas bancas de feirantes brasileiros, como é o caso dos advindos dos assentamentos rurais (Figura 3).

\section{Figura 3 - Produtos de hortifrúti oferecidos pelos feirantes bolivianos na feira de quarta-feira no centro de Ladário.}

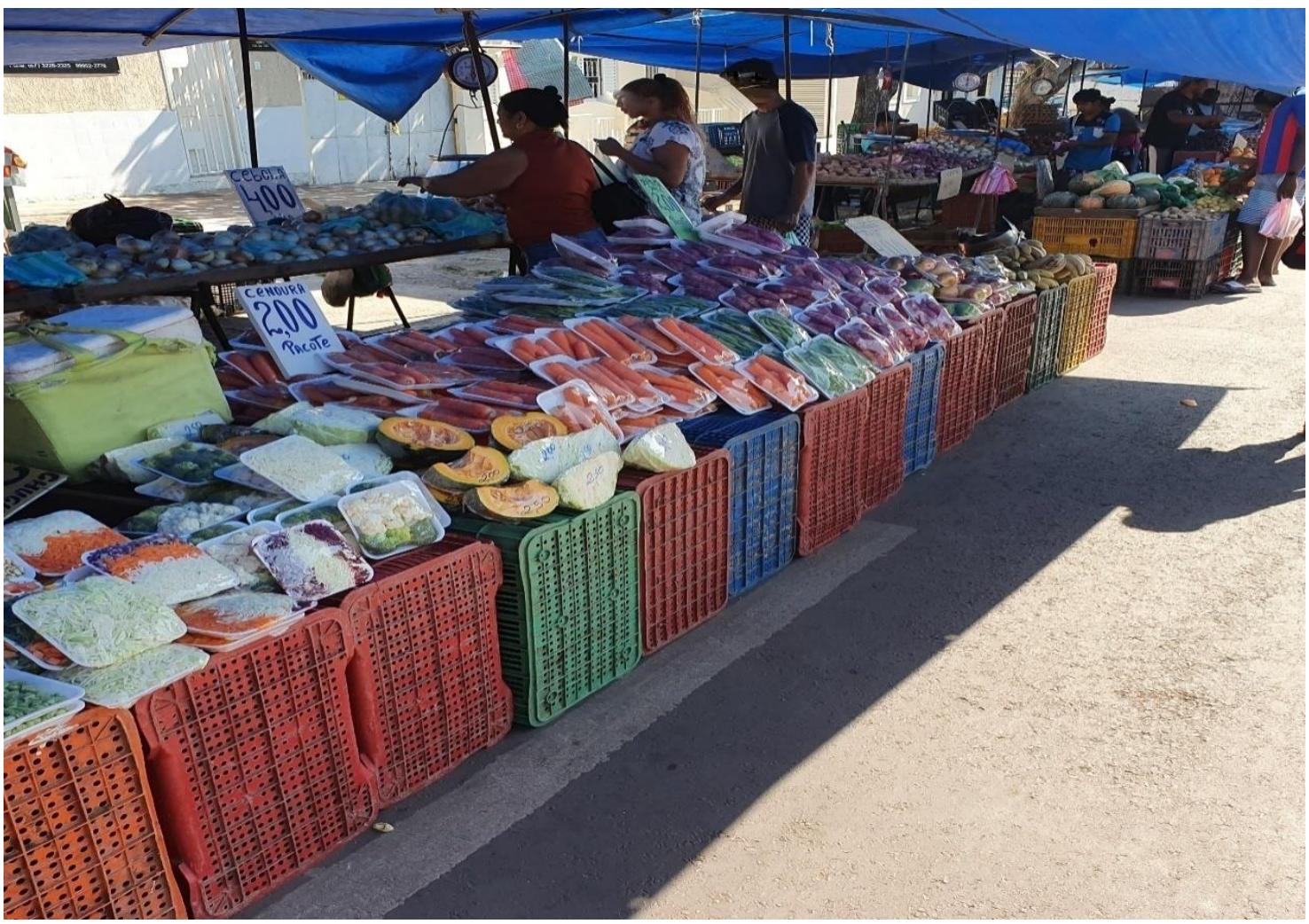

Fonte: Trabalho de campo 2019.

Observamos através da pesquisa de campo, que as bancas bolivianas apresentam uma maior variedade de produtos, e podemos observar também, uma diferença considerável no tamanho e na estrutura das bancas dos feirantes bolivianos em comparação às bancas dos feirantes brasileiros. Isso ocorre, pois, os bolivianos em sua maioria são revendedores e não, produtores como os brasileiros, pois comercializam não somente o que eles produzem, mas também os produtos dos demais fornecedores.

Tais fornecedores se alternam entre locais ou mesmo de outras regiões, como Campo Grande, Capital do estado do Mato Grosso do Sul, como originários de outros estados, como produtos da Ceasa, localizado em São Paulo ou mesmo frutas advindas do estado do Paraná.

Além dos hortifrútis, outros produtos são ofertados nas feiras livres, como; brinquedos, alguns eletrônicos, acessórios de informática, além de grande variedade de roupas (Figura 4).

ParaOnde!?, Porto Alegre, v.13, n.2, p. 165-182, 2020.http://seer.ufrgs.br/paraonde Edição Especial - VII Seminário Internacional de Estudos Fronteriços 


\section{Figura 4 - Barraca de eletrônicos, cobertores e guarda-chuvasn feira de quarta-feira no centro de Ladário.}

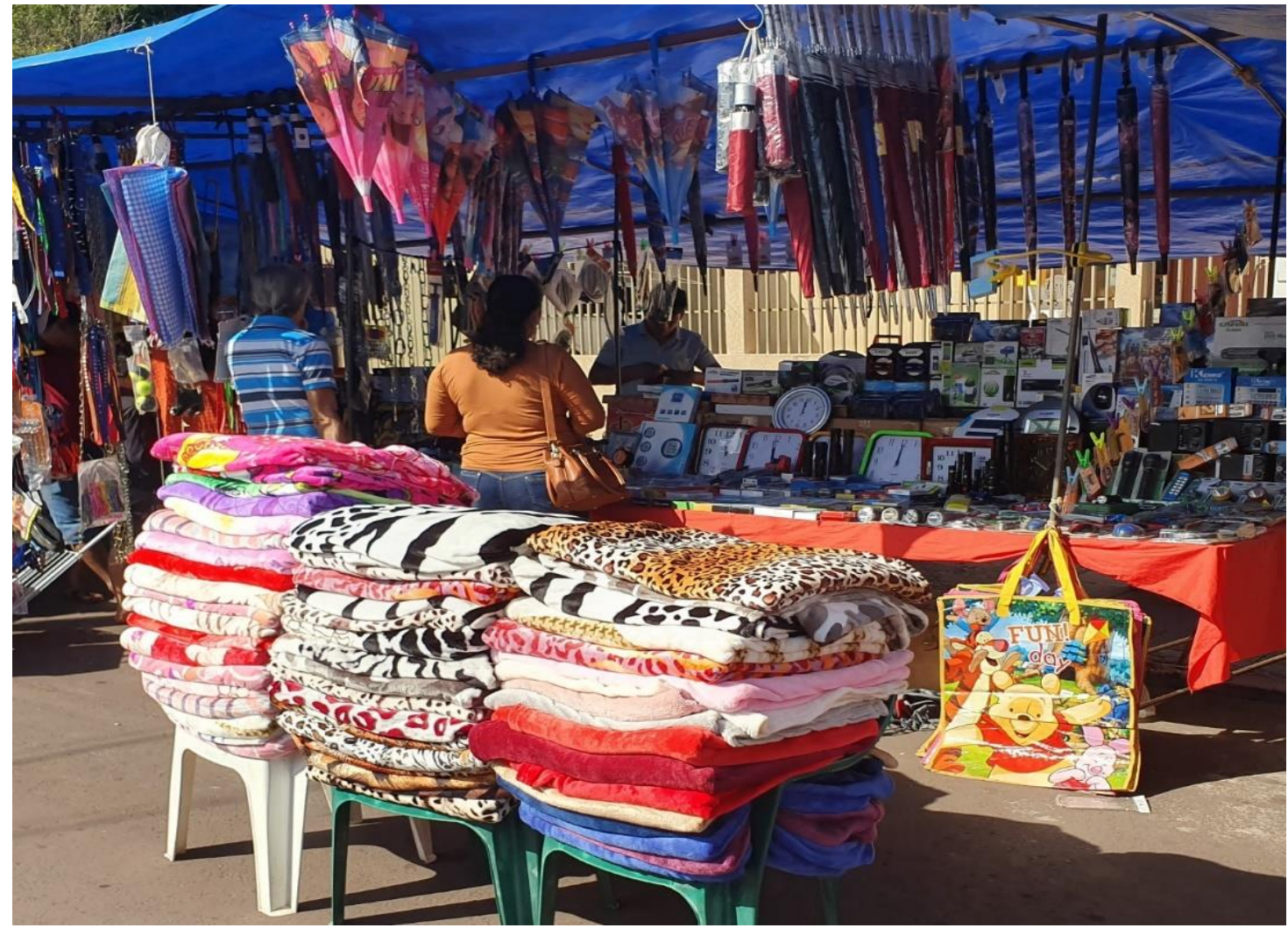

Fonte: Trabalho de campo 2019.

Outra característica das feiras livres de Corumbá e Ladário-MS, são as barracas de roupas, para todas as faixas etárias. Existem bolivianos que comercializam roupas novas e outros que vendem roupas já usadas, que localmente são conhecidas como "roupas do monte" ou "montão", são chamadas assim pela forma como são organizadas.

De acordo com Ferreira (2015), essas roupas usadas são advindas de doações, em especial do Estados Unidos, Reino Unido, Alemanha e países baixos. Esses produtos são transportados em containers, e chegam até o Chile pelos portos de Arica e lquique.

Segundo Ferreira (2015), esse comércio chegou na Bolívia a partir de 1994, iniciando em Oruro, posteriormente chegando até Santa Cruz de la Sierra, capital do departamento de Santa Cruz, onde o comércio dessas roupas se encontra em duas feiras livres, as de Cumavi e de Santos Dumont. Com isso, os comerciantes que revendem essas roupas nas feiras livres de Corumbá e Ladário-MS, viajam até Santa Cruz de La Sierra, compram engradados dessas roupas usadas e trazem para serem revendidas no lado brasileiro da fronteira (Figura 5). 
Figura 5 - Roupas usadas revendidas nas feiras livres de domingo no centro de Corumbá.

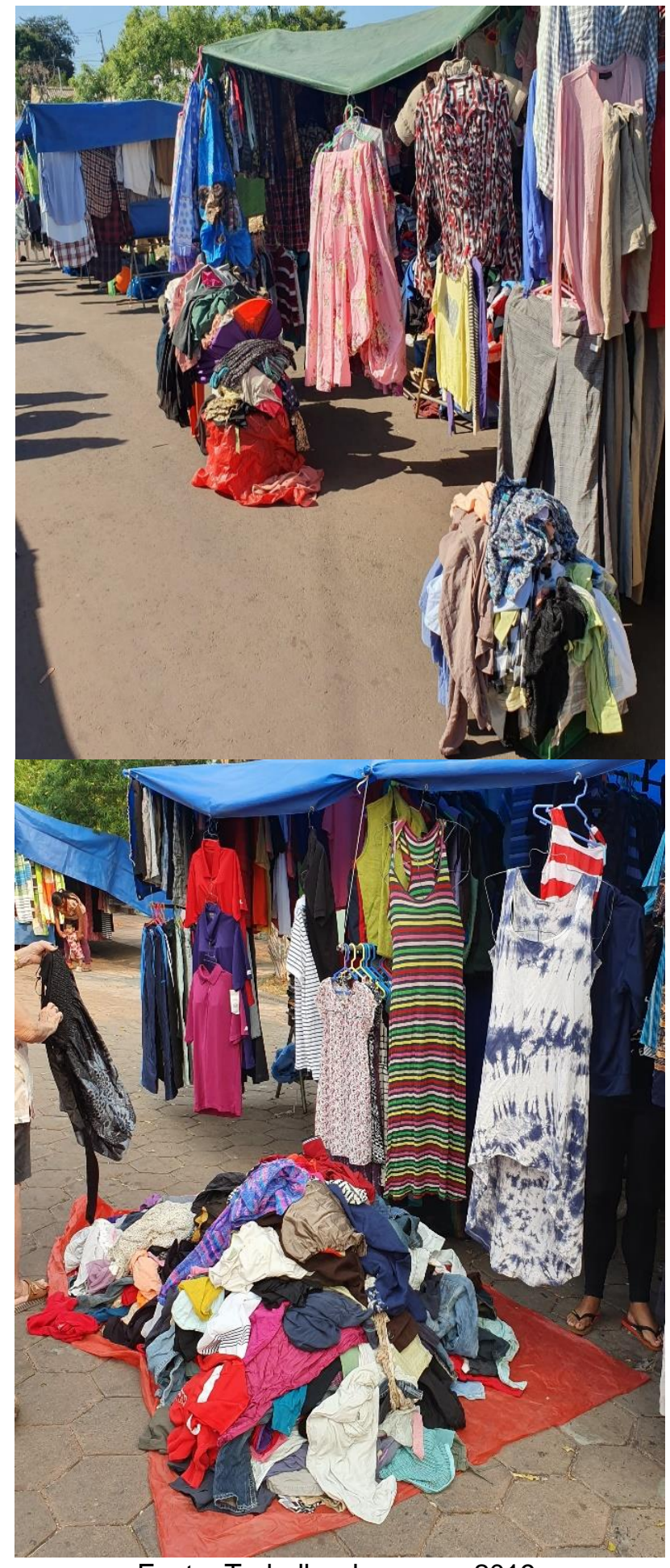

Fonte: Trabalho de campo 2019

Além das feiras livres diurnas, existem também as feiras noturnas, sendo uma realizada na cidade de Corumbá aos sábados, no bairro Maria Leite e outra em Ladário, nas quintas feiras no bairro Almirante Tamandaré. Elas 
apresentam características peculiares como a maior presença de bancas voltadas para refeições ao ar livre.

De acordo com uma entrevistada na feira noturna de Ladário "prefiro vir à noite, pois não é tão quente como de dia, consigo andar mais, escolher melhor o que comprar, sem pressa por causa do calor".

Outras pessoas frequentam a feira para aproveitar a comidas que são vendidas no local, tais como: pastel, churrasquinho, bolo em pedaço, salgados, além de comidas típicas como arroz de carreteiro, porção de peixes locais com arroz e mandioca cozida (Figura 6).

\section{Figura 6 - Feira noturna na quinta-feira no bairro Almirante Tamandaré cidade de Ladário-MS}
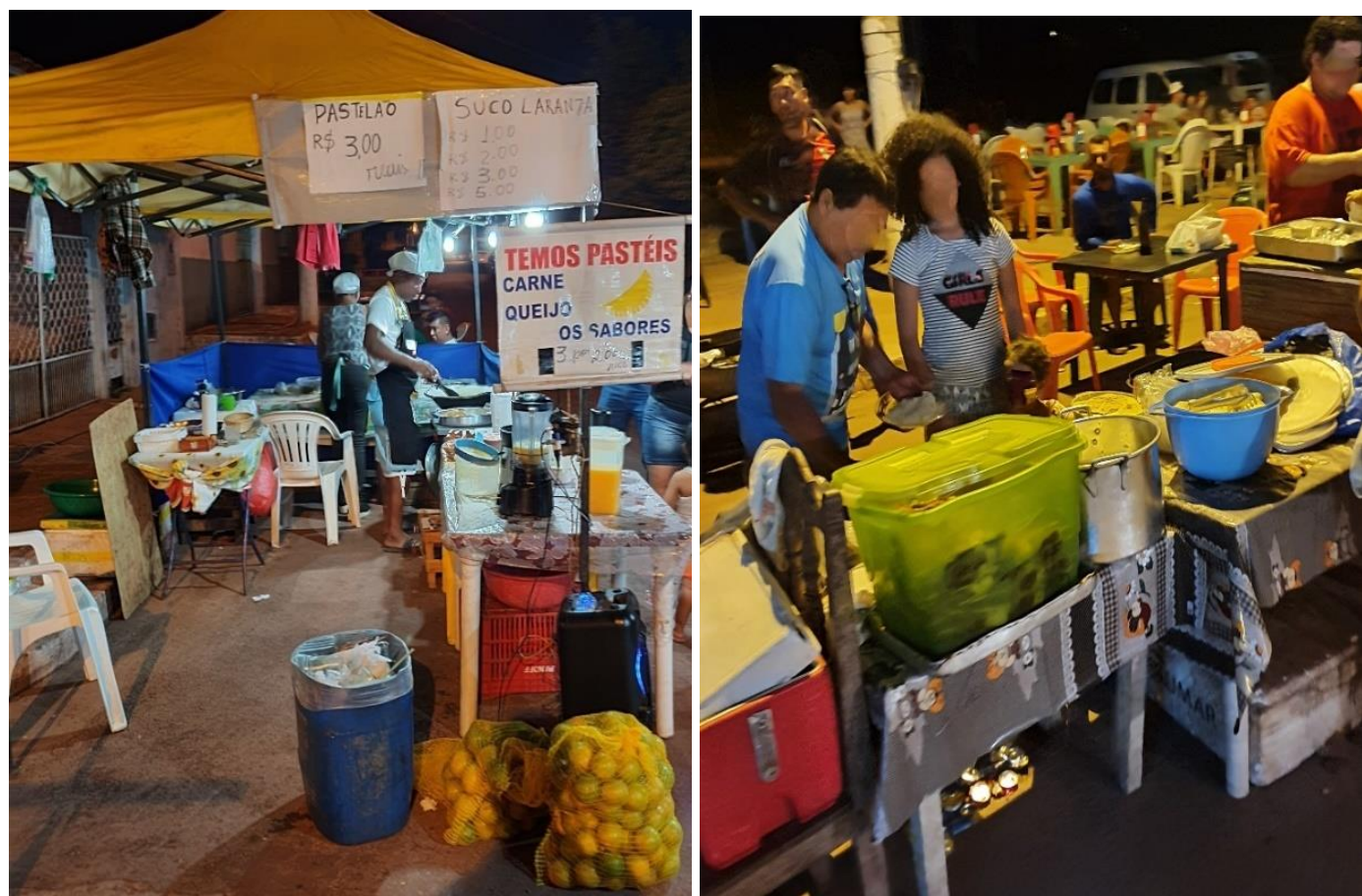

Fonte: trabalho de campo 2019.

Com isso observamos que as feiras são locais de trocas e convivência, fazem parte do cotidiano dos corumbaenses e ladarenses. Em relação aos comerciantes bolivianos, buscamos compreender em conversa informal, como a fronteira influencia na comercialização em feiras. Para eles, a forma de se adquirir os produtos ofertados, gerando oportunidades ou mesmo dificuldades por causa da fiscalização que pode ocorrer próxima ao limite fronteiriço.

Para os feirantes bolivianos quando produtos no Brasil estão com preços mais altos, como as hortaliças, eles conseguem trazer esses alimentos do lado boliviano da fronteira. Com isso conseguem oferecer preços mais baixos fazendo uso desse fator fronteiriço.

Porém, alguns desses comerciantes relataram que quando produtos elevam muito o preço no lado brasileiro, a fiscalização feita pela receita e 
polícia federal aumenta nessa passagem de fronteira. Com isso notaram que existe uma relação de controle movida por alguma racionalidade capaz de aumentar a vigilância e fiscalização nesse espaço fronteiriço.

\section{Feiras livres nos municípios de Ponta Porã (BR)}

Em Ponta Porã, acontecem quatro feiras itinerantes realizadas nos dias semanais de quarta-feira e sexta-feira das 7:00 h. as 13:00 h., todas realizadas por camponeses do Assentamento Itamarati. A Figura 7 apresenta a localização destas feiras.

\section{Figura 7 - Localização das feiras livres em Ponta Porã - MS}

\section{Localização das feiras livres em Ponta Porã}

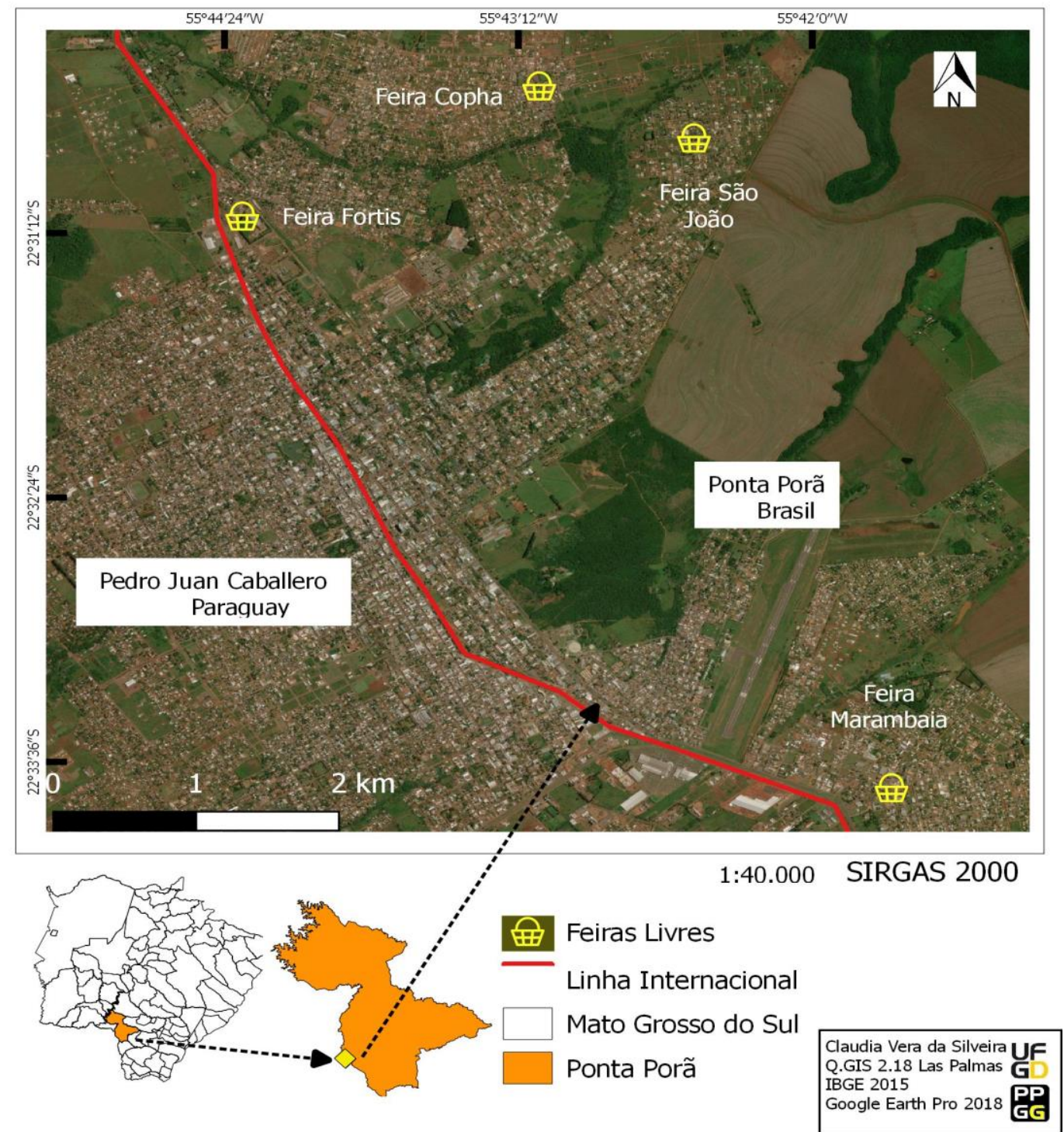

Fonte: SILVEIRA, C. V. (2019).

ParaOnde!?, Porto Alegre, v.13, n.2, p. 165-182, 2020.http://seer.ufrgs.br/paraonde Edição Especial - VII Seminário Internacional de Estudos Fronteriços 
Figura 8 - Feira da Cophafronteira
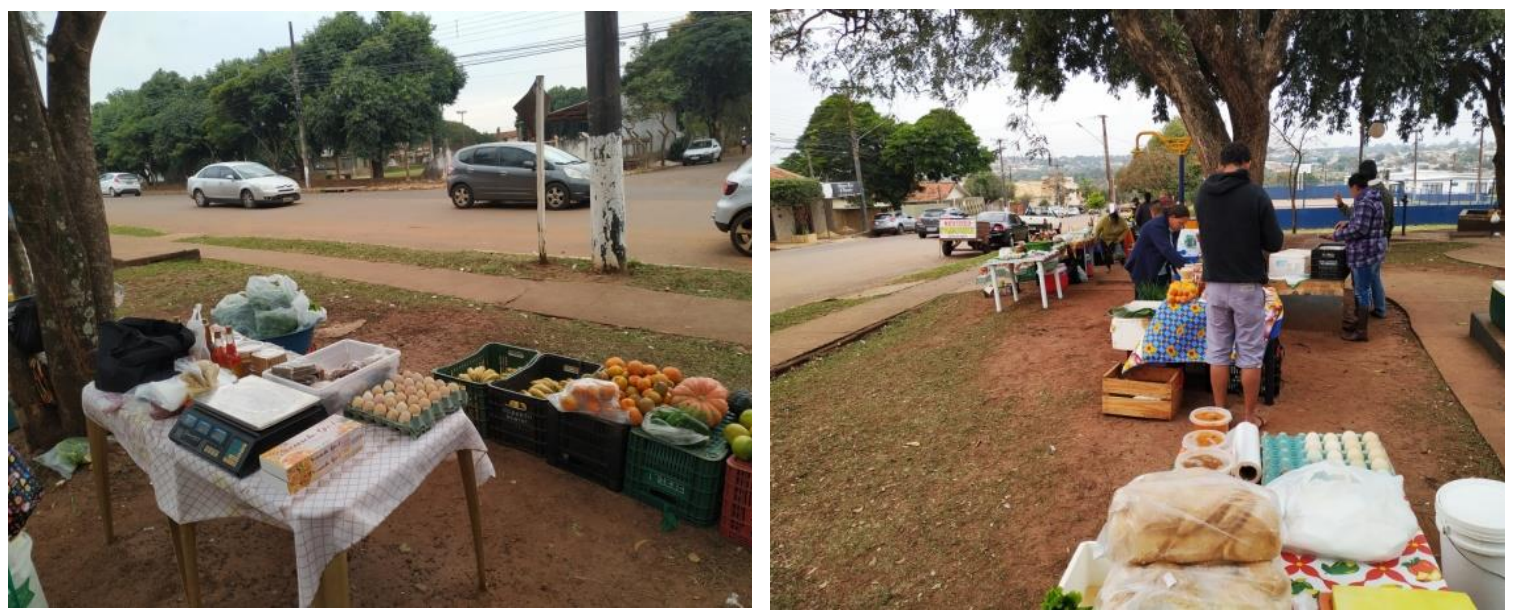

Fonte: Trabalho de campo, SILVEIRA (2019).

A Feira da Copha acontece na pracinha do bairro Cophafronteira, onde se comercializa produtos in natura como frutas, legumes e verduras. Também verificamos que os camponeses comercializam leites e seus derivados, como queijos e doce de leite, além de uma variedade de outros doces como rapadura, amendoim doce, cocada, etc. Ovos caipiras, farinhas, pães caseiros e temperos tipo sal com alho, açafrão, colorau, pimentas, licores e melados também são comercializados.

De acordo com os feirantes, os produtos caseiros possuem boa aceitação dos fregueses. Observou-se que parte dos feirantes realizam o registro de suas vendas diárias, fazendo anotações em cadernos pequenos, registrando, por exemplo, a data da feira, o produto vendido, a quantidade vendida e o valor dos produtos. Em conversa com um dos feirantes, tivemos acesso a um desses cadernos de anotações conforme a Figura 9.

Figura 9 - Feira da Cophafronteira
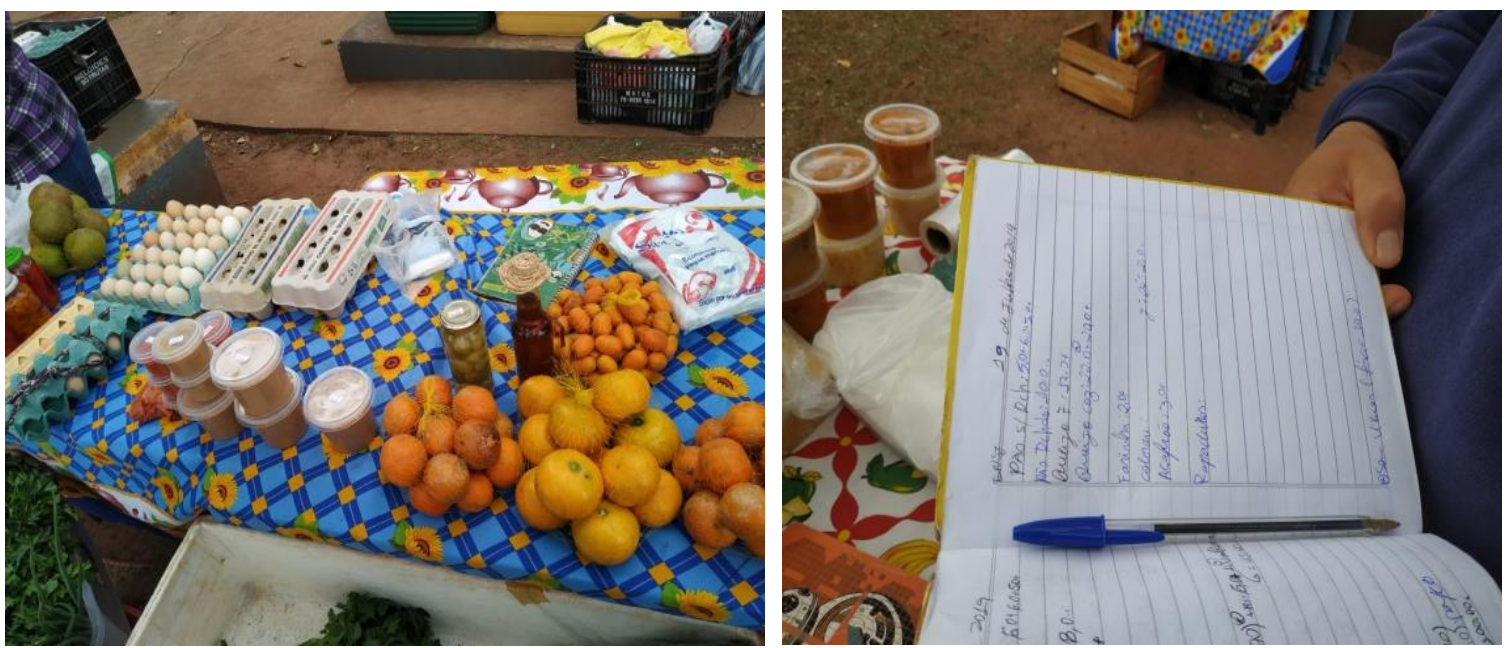

Fonte: Trabalho de campo, SILVEIRA (2019).

ParaOnde!?, Porto Alegre, v.13, n.2, p. 165-182, 2020.http://seer.ufrgs.br/paraonde Edição Especial - VII Seminário Internacional de Estudos Fronteriços 
Verificamos também, que os feirantes zelam pelas regras sanitárias relacionados ao cuidado e conservação de alimentos como, por exemplo, os queijos são embalados e armazenados em caixas conservadoras como apresenta a Figura 10.

Figura 10 - Queijos comercializados na Feira da Cophafronteira.
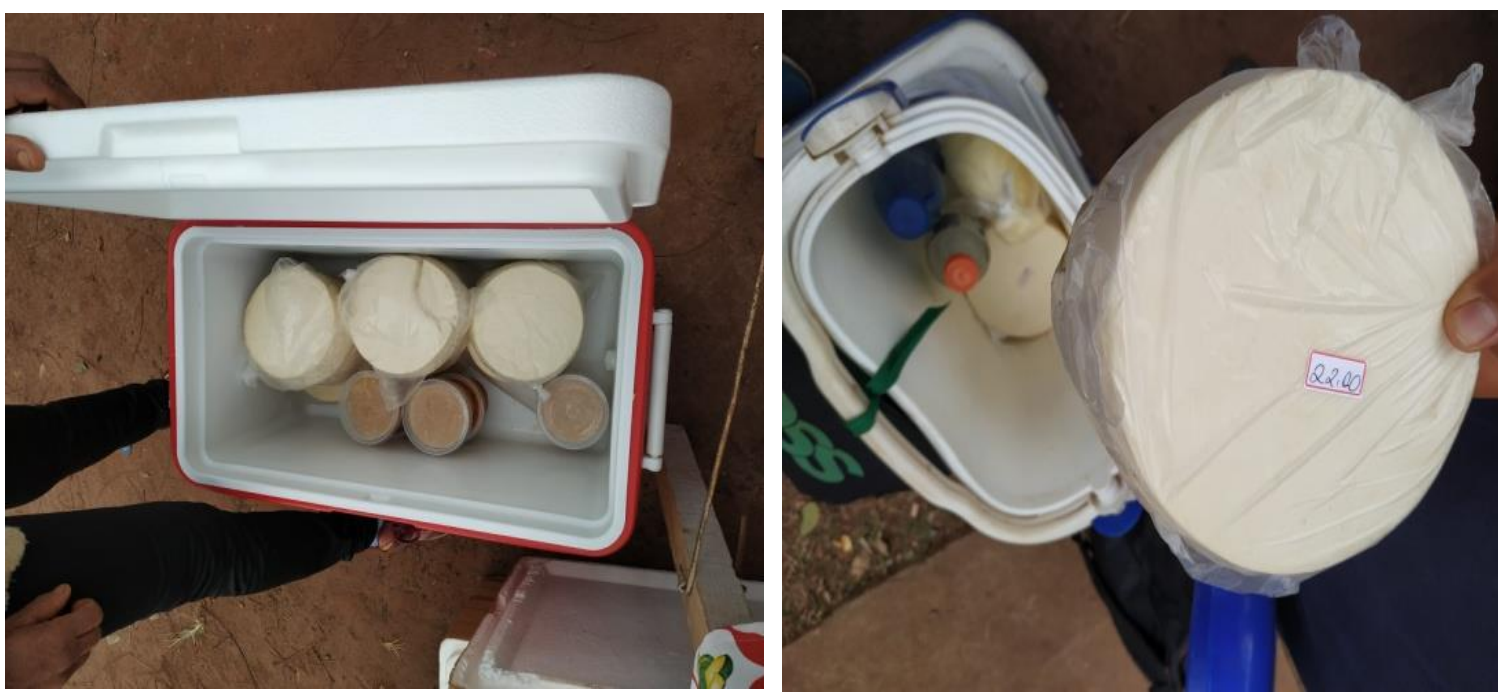

Fonte: Trabalho de campo, SILVEIRA (2019).

Somam-se em aproximadamente 75 camponeses participantes da organização das feiras itinerantes. Um dos feirantes mencionou a importância das feirinhas, pois permite a comercialização da produção dos seus respectivos lotes e já proporcionou a possibilidade de permanecer na terra, pois já houve momentos em que alguns camponeses "pensaram em desistir e ir pra cidade, mas agora com a feira aqui, ficou melhor pra gente vender a produção e ajuda no nosso sustento" (Entrevista realizada com o SM 19/06/2019).

Além da sociabilidade dos feirantes entre si e para com os compradores, existem alguns feirantes que vendem na caderneta para alguns fregueses moradores do bairro, "que pagam a conta no final do mês". É interessante registrar que as feiras são organizadas por meio de associações e recebem importante apoio das instituições públicas como a Prefeitura da cidade, esse apoio se materializa através transporte ofertado aos feirantes e seus respectivos produtos, o transporte se dá entre o assentamento até o local da feira, de acordo um feirante, "sem esse apoio fica difícil para gente se organizar e vir pra cá" (Entrevista realizada ao SM em 19/07/2019). No que se refere à questão monetária, nas feiras do lado brasileiro são aceitas as moedas real e guarani, porém em menor proporção do que ocorre nas feiras do lado paraguaio como veremos a seguir.

\section{Feiras livres em Pedro Juan Cabellero (PY)}

No município de Pedro Juan Caballero existem duas feiras localizadas no centro da cidade, que ocorrem duas vezes por semana: todas as terçasfeiras e sábados no período matutino. Estas feiras são organizadas por associações de produtores camponeses especializados em hortifrutis, e

ParaOnde!?, Porto Alegre, v.13, n.2, p. 165-182, 2020.http://seer.ufrgs.br/paraonde Edição Especial - VII Seminário Internacional de Estudos Fronteriços 
recebem apóio de entidades públicas como o Governo Departamental de Amambay e o Governo Nacional do Paraguai, uma destas feiras, por exemplo, tem 20 anos de trajetória e para sua formação e consolidação teve o auxílio de instituições de ensino como a Faculdade de Ciências Agrárias da cidade de Pedro Juan Caballero, esta feira é conhecida como "Feria Libre de Produtores Hortigranjeros". A Figura 11 apresenta a localização das feiras livres de Pedro Juan Caballero.

Figura 11 - Localização das feiras livres de Pedro Juan Caballero

\section{Localização das Feiras Livres de Pedro Juan Caballero}

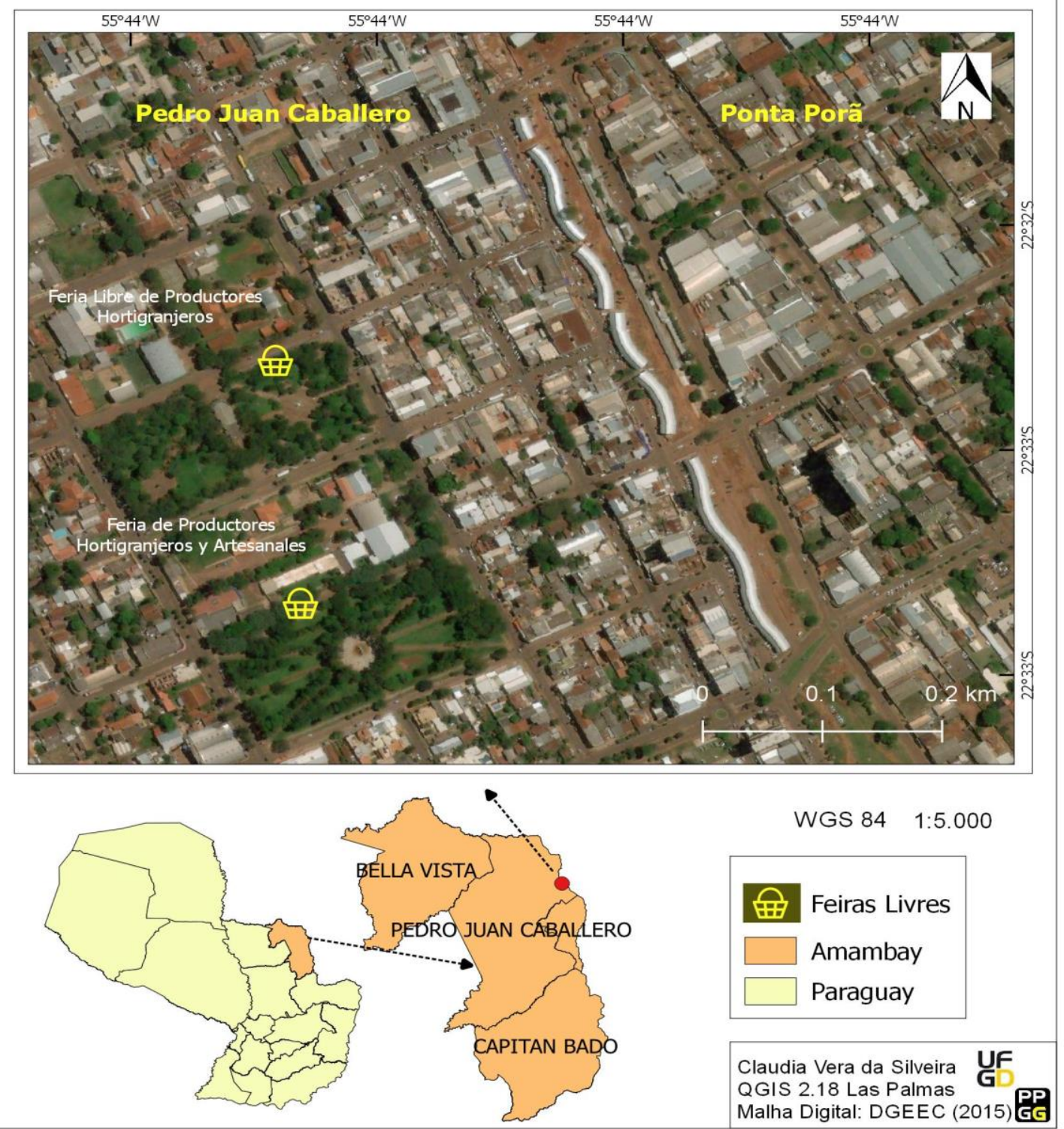

Fonte: SILVEIRA (2019).

Observamos uma forte presença de mulheres camponesas na feira responsáveis pela comercialização produtos de seus respectivos lotes. Estas mulheres geralmente são acompanhadas de filhos pequenos e pelos seus

ParaOnde!?, Porto Alegre, v.13, n.2, p. 165-182, 2020.http://seer.ufrgs.br/paraonde Edição Especial - VII Seminário Internacional de Estudos Fronteriços 
companheiros. Os filhos maiores ficam nos lotes com algum parente, pois não há lugar para todos os membros da família no meio de condução utilizado para o descolamento dos lotes até a cidade, muitas vezes estes transportes são variados como ônibus, camionetes e principalmente moto-carrinho.

Em trabalho de campo verificamos que a produção mandioca, milhos entre outros cuidados no lote são responsabilidade do homem e o cuidado da horta e dos animais menores como galinhas, patos, porcos é responsabilidade da mulher. Em conversa com uma das mulheres da feira, está nos menciona que a ajuda mútua com o companheiro é muito importante, e que eles sempre se ajudam no lote. O idioma que predomina entre os feirantes é o guarani, seguido espanhol e em menor magnitude encontra-se o idioma português por causa da condição de fronteira com o Brasil e também devido a presença de brasileiros camponeses que residem nas colônias do lado paraguaio.

Em relação à comercialização um dos camponeses feirantes comentou que a presença de clientes brasileiros que moram em Ponta Porã é muito importante para a feira, pois eles são freqüentes e fazem circular a economia com sua moeda que é o real. Verificamos que é comum a circulação de moedas como guarani e real na feira e, isso permite a conversão de valores quase que instantaneamente entre os feirantes e os clientes. Por exemplo, aqui outro feirante nos disse que faz a conversão de cabeça e já está acostumado em realizar transação de real e guarani ou vice-versa, por exemplo, que um pé de alface na feira custa 1.500 guarani o que corresponde a 1 real. Cabe destacar que a localização desta feira dista a 200 metros do outro lado da fronteira.

Os produtos comercializados na feria são: mandiocas, cenoura, beterraba, abóboras, couve-flor, brócolis, alface, salsinha, cebolinha, couve em folhas, rúcula, agrião, repolho, tomates, frutas como banana, laranja, manga, abacaxi, abacate, acerola entre outras, vale lembrar que todas as frutas, verduras e legumes vendidos na feirinha são da estação e são produtos frescos que vêm direto dos lotes e/ou da horta. A Figura 12 apresenta a feirinha em Pedro Juan Caballero. Figura 12. Feira em Pedro Juan Caballero.

Figura 12 - Feira de Pedro Juan Caballero.
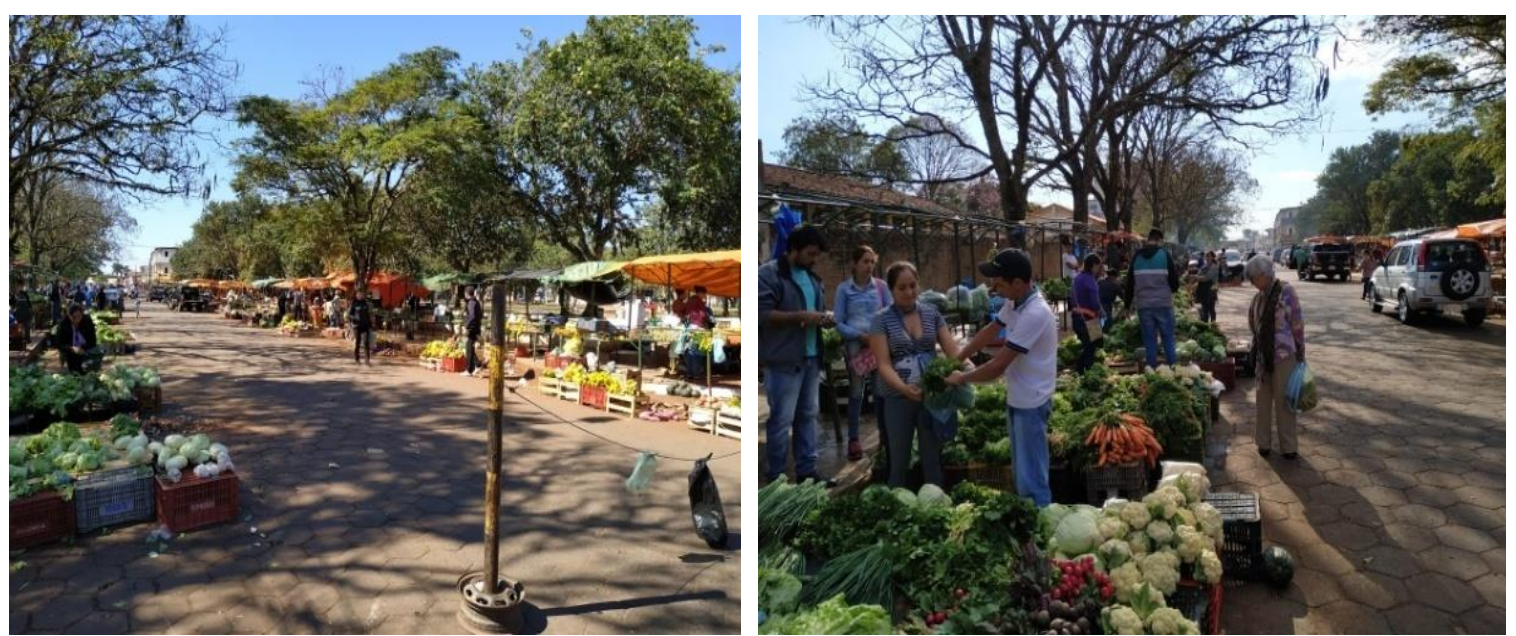

Fonte: Trabalho de campo, SILVEIRA (2019).

ParaOnde!?, Porto Alegre, v.13, n.2, p. 165-182, 2020.http://seer.ufrgs.br/paraonde Edição Especial - VII Seminário Internacional de Estudos Fronteriços 
A organização das barraquinhas é realizada por comitês de acordo com as colônias da qual os feirantes são oriundos, os membros destes comitês por sua vez também fazem parte de uma associação de produtores da feira. Desta forma os membros de um determinado comitê são geralmente vizinhos nas barraquinhas da feira e também da colônia onde residem. A feira é realizada na rua Perpétuo Socorro com a Natalicio Talavera e Carlos Antonio López, verificamos que nos dia de terça-feira é destinada uma quadra da rua, lado direito e esquerdo, cabe ressaltar que toda essa área é arborizada, como é possível observar na Figura 1. No lado direito encontra-se uma das mais antigas praças da cidade cujo nome é Plaza Pedro Juan Caballero que e é palco de comemorações da pátria, inclusive essa praça foi erguido em homenagem aos heróis da independência do Paraguai, conhecido como próceres de mayo. Neste caso Goiris (1999) destaca que o nome antigo da cidade era Punta Porá e por determinação do governo nacional a cidade passou a ser receber o nome de Pedro Juan Caballero em homenagem a um dos heróis da independência do Paraguai em 1815. No lado esquerdo temos o colégio mais antigo da cidade que é o Escuela Don Carlos Antonio López.

Geralmente ao sábados o número de feirante é maior e, é utilizada mais uma quadra chegando até a rua Teniente Herrero, neste caso é utilizado somente o lado direito da rua que também é arborizada e faz parte de outra praça denominada Plaza Panchito López, o lado esquerdo faz parte de um clube particular e tradicional da cidade.Todas as ruas mencionadas contam com uma infra-estruturacomposta por barracas de metal disponíveis para os feirantes. Os dias de feira o acesso à rua é interdita (Figura 1), porém o que se observa é que alguns clientes com bicicletas, motocicletas e /ou veículos de passeio como carros e camionetas ultrapassa a linha e transitam dentro do espaço destinado para a feira para realizar suas compras, sem muitas vezes descerem dos seus meios de transporte. Isso causa incômodo para alguns fregueses, porém os feirantes aprovam esse transito, pois segundo eles é rapidinho, pois o freguês chega e pega o produto e continua o seu trajeto, na palavras do feirante: "enterobe'ao ganá, hikuáiojoguá ore produtohaupe 'apeichanteoí, ymaguaré", traduzindo em espanhol: "todos salimos ganando, ellos compran nuestroproductos rapidito y es os iempreexistió". A Figura 13 apresenta o transito de veículos e pedreste no local da feira.

Em relação às feiras do lado brasileiro verificamos que existem quatros feiras itinerante em Ponta Porã realizadas em quatro bairros da cidade, nos dias de quarta-feira e sexta feira no período matutino. Os feirantes são do assentamento Itamarati.

ParaOnde!?, Porto Alegre, v.13, n.2, p. 165-182, 2020.http://seer.ufrgs.br/paraonde Edição Especial - VII Seminário Internacional de Estudos Fronteriços 
Figura 13 - Trânsito de veículos e pedestres no local da feira.
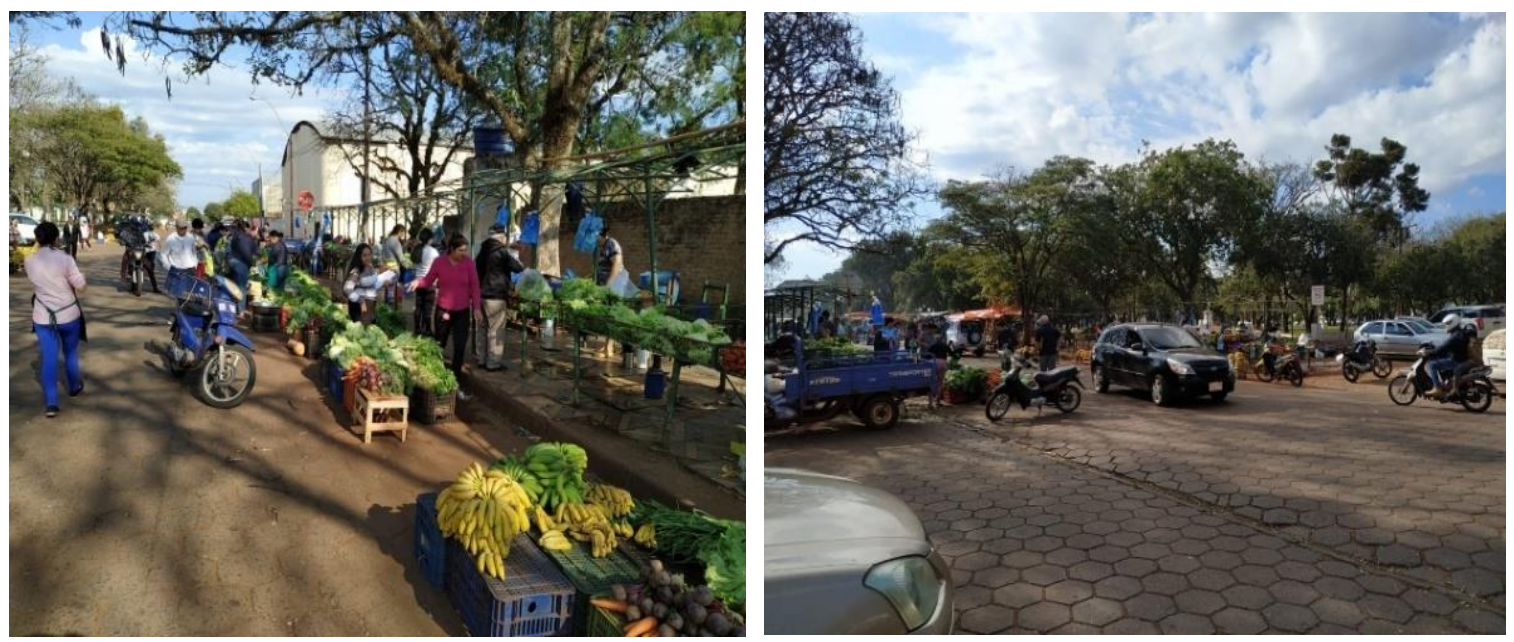

Fonte: Trabalho de campo, SILVEIRA (2019).

Geralmente os feirantes organizam toda a produção na tarde de segunda-feira e sexta-feira no período vespertino e noturno, a produção é armazenada em caixas plásticas e/ou madeiras, sacos com capacidade para $50 \mathrm{~kg}$ entre outros tipos de embalagens, e posteriormente armazenada nos meios de transportes. A Figura 14 apresenta um meio de transporte utilizado pelos feirantes.

Figura 14 - Moto-carrinho: um dos meios de transportes utilizados pelos feirantes.
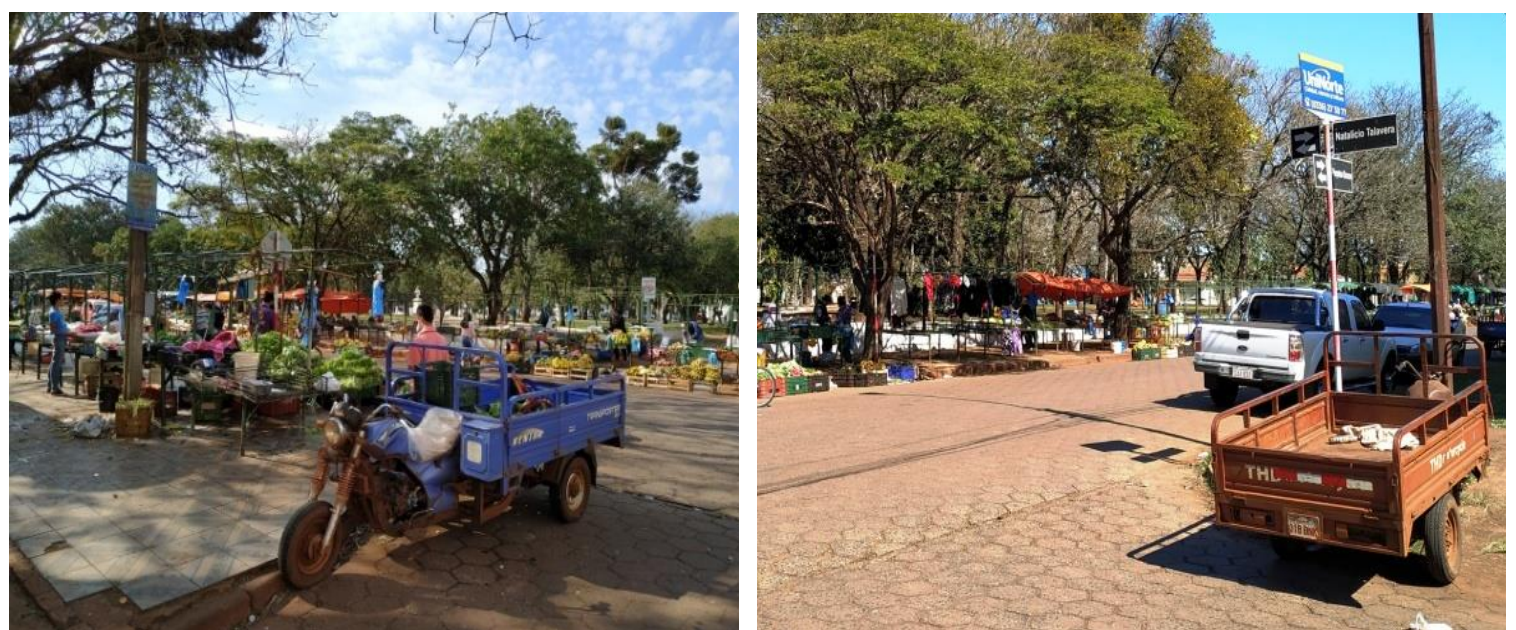

Fonte: Trabalho de campo, SILVEIRA (2019).

Outro produto que também é vendido bastante de acordo aos feirantes são os chamados "poháro'ysã" ou ervas medicinais que são utilizados como bebidas para o tereré, mate e/ou chá. Além disso, encontram-se mudas de plantas ornamentais, frutais e medicinais, cabe destacar que todas essas plantas são produzidas na horta familiar (Figura 15). 


\section{Figura 15 - Pohãro'ysã (raízes e plantas medicinais) e mudas de plantas comercializadas na feirinha.}
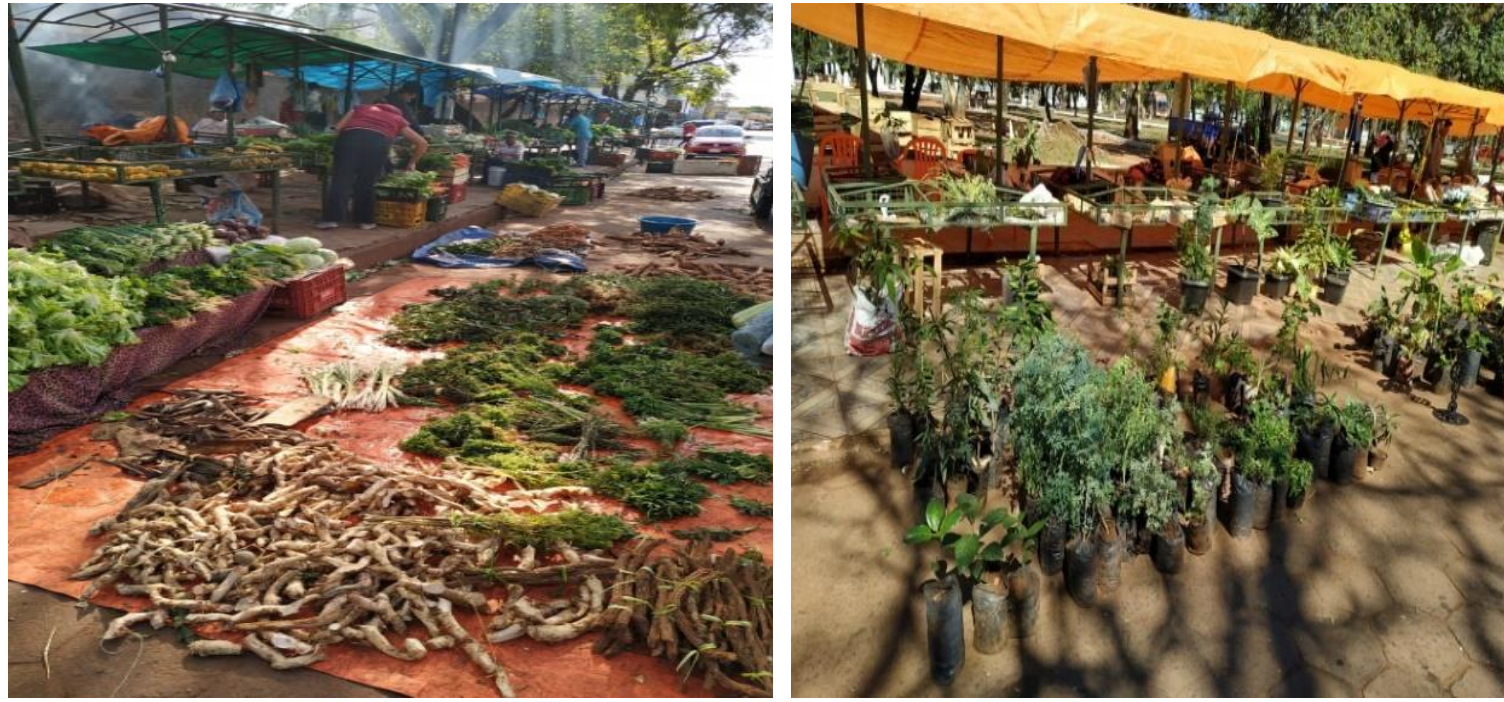

Fonte: Trabalho de campo, SILVEIRA (2019).

Produtos com valores agregados também são comercializados, mandioca descascada pelas mulheres e depositadas em baldes ou bacias com água, amendoim torrado, amendoim triturado, queijos, melado, fubá (farinha de milho) e milho verde debulhado e/ou ralado trabalho realizado também pelas mulheres camponesas no local da feira são produtos tradicionais utilizados para a elaboração da sopa paraguaia e a chipa guasú.

Figura 16 - Produtos com valor agregado comercializados na feirinha.
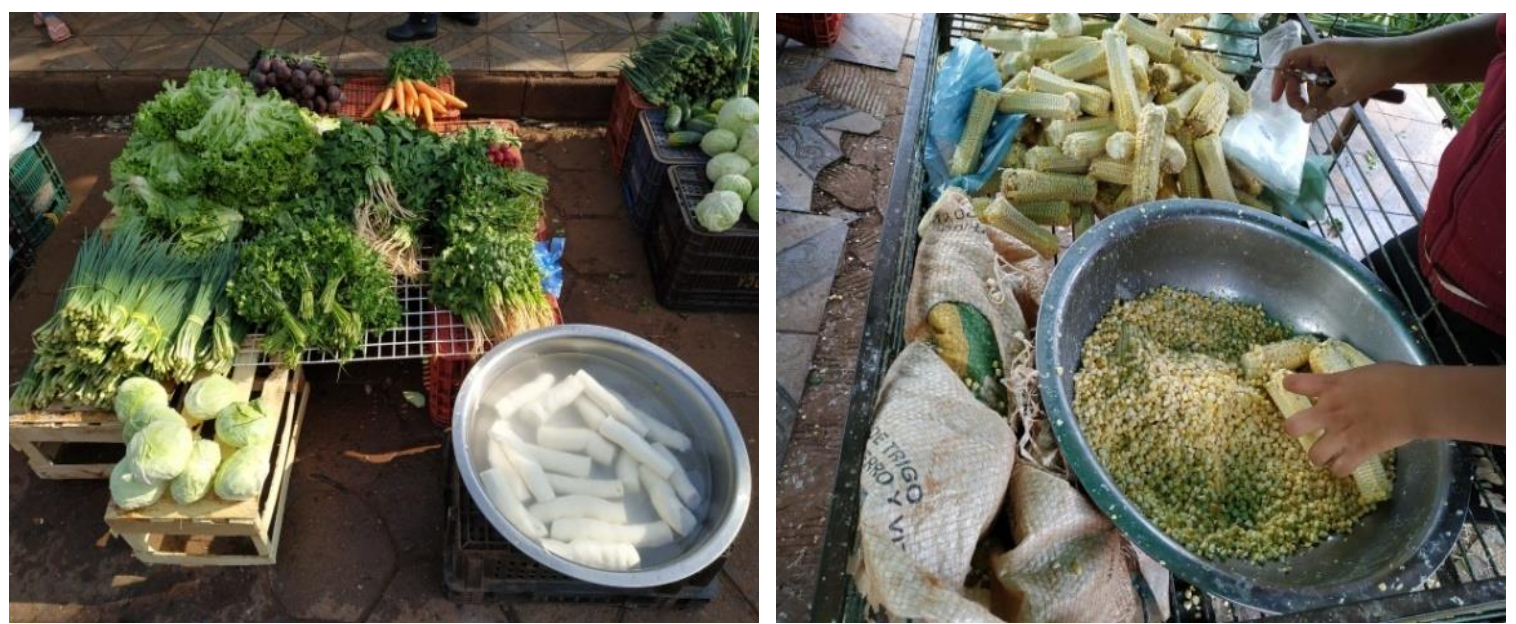

Fonte: Trabalho de campo, SILVEIRA (2019).

Também é comercializado polvilho azedo, carne de ovelha e porco, frango e ovos caipira, este produto tem grande aceitação dos fregueses fronteiriços e logo nas primeiras horas em que acontece a feira as carnes, por exemplo, são todos vendidos.

ParaOnde!?, Porto Alegre, v.13, n.2, p. 165-182, 2020.http://seer.ufrgs.br/paraonde Edição Especial - VII Seminário Internacional de Estudos Fronteriços 


\section{Considerações finais}

As feiras livres se apresentam nesse trabalho como espaços de convivência, são locais de trocas comerciais e culturais, onde a fronteira se apresenta como elemento dinamizador dessa atividade.

O arranjo espacial dessas fronteiras analisadas influencia na forma e quantidade de feiras livres que existem nessas cidades fronteiriças. Quando analisamos as cidades de Ponta Porã (BR) e Pedro Juan Caballero observamos a inexistência de fiscalização nessa passagem, o que possibilita uma maior fluidez de mercadorias e de pessoas, que podem frequentar ambos os lados desse limite fronteiriço e fazer suas compras, onde o preço for mais barato.

Já na cidade de Corumbá e Ladário-MS pelo arranjo espacial dessa fronteira existe um controle maior por parte das instituições de controle, o que impossibilita uma maior fluidez de pessoas e produtos. Com isso as feiras tendem a se concentrarem mais no lado brasileiro dessa fronteira. Se espalhando por toda a cidade, pois a população ladarense e corumbaense dificilmente atravessaria esse limite fronteiriço para fazer suas compras nas feiras livres do lado boliviano.

\section{Referências}

BENEDETTI, Alejandro. Lugares de frontera y movilidades comercial es en el sursudamericano: una aproximación multiescalar. IN: COSTA, E.A.; COSTA, G.V.L.; OLIVEIRA, M.A.M. Fronteiras em foco. Campo Grande: Ed. UFMS, p. 33-55, 2011.

CUYATE, Rozilene. Fronteira e territorialidade dos camponeses do Assentamento 72, Ladário-MS. 2015. p, 81. Dissertação (Mestrado em Estudos Fronteiriços). Câmpus do Pantanal, Universidade Federal de Mato Grosso do Sul. Corumbá, 2015.

FERREIRA, Fernanda Loureiro. "Brechó fronteiriço": a comercialização de roupas usadas nas feiras livres de Corumbá (BR). 2015, p. 118. Dissertação (Mestrado em Estudos Fronteiriços). Câmpus do Pantanal, Universidade Federal de Mato Grosso do Sul. Corumbá, 2015.

GOIRIS, F. Descubriendo La Frontera: historia, sociedad y política en Pedro Juan Caballero. Ponta Grossa: INPAG, 1999.

MACHADO, L. O. Estado, territorialidade, redes. Cidades gêmeas na zona de fronteira sul-americana. P. 243-284. In: Continente em Chamas: Globalização e território na América Latina. Org. Maria Laura Silveira. Civilização Brasileira, Rio de Janeiro. Maio, 2005.

SANTOS, Ramona Catarina Ortiz; OLIVEIRA, M. A. M. Trabalhadores Bolivianos em Feiras Livres na Cidade de Corumbá, MS. Relatório Final PIBIC do projeto de Iniciação Científica do CNPq 2011/2012. UFMS/CPAN,

ParaOnde!?, Porto Alegre, v.13, n.2, p. 165-182, 2020.http://seer.ufrgs.br/paraonde Edição Especial - VII Seminário Internacional de Estudos Fronteriços 
Corumbá-MS, 2012.

SATO, Leny. Processos cotidianos de organização do trabalho na feira livre. Psicol. Soc. [online]. 2007, vol.19, n.spe, P. 95-102. ISSN 1807-0310.

SILVA, Celma Balbina. Economia Informal em Corumbá/MS: A chamada "Feirinha Boliviana" e pequenos comerciantes ambulantes - realidade e cotidiano. UFMS/CPAN, 2003. Monografia de Graduação. Corumbá-MS, 2003.

\section{AGRADECIMENTOS}

Os autores agradecem a CAPES (Coordenação de Aperfeiçoamento de Pessoal de Nível Superior) pela Bolsa de Estudos no nível de Doutorado. 